\title{
HUBUNGAN ANTARA KECERDASAN EMOSIONAL DAN INTERNAL LOCUS OF CONTROL DENGAN PERILAKU PROSOSIAL PADA PELAJAR DI SMA NEGERI 10 YOGYAKARTA
}

\author{
Meidy Dewita Artianasari Noija ${ }^{1}$, Kamsih Astuti ${ }^{2}$ \\ ${ }^{12}$ Universitas Mercu Buana Yogyakarta \\ ²tutik.umby@gmail.com
}

\begin{abstract}
ABSTRAK
Penelitian ini bertujuan untuk mengetahui mengetahui hubungan antara kecerdasan emosional dan internal locus of control dengan perilaku prososial pada pelajar di SMA Negeri 10 Yogyakarta. Metode yang digunakan dalam penelitian ini adalah metode skala. Metode pengumpulan data dilakukan dengan menggunakan metode skala. Teknik pengambilan sampel yang digunakan adalah non random sampling. Subyek yang dilibatkan dalam penelitian ini sebanyak 80 orang siswa Kelas XI IPA 1, Kelas XI IPA 2 dan Kelas XI IPS 2 SMA Negeri 10 Yogyakarta. Analisis data dilakukan dengan menggunakan analisis korelasi Product Moment dan analiais regresi berganda. Hasil penelitian menunjukkan bahwa: (1) Kecerdasan emosional mempunyai hubungan positif dan signifikan dengan perilaku prososial pelajar di SMA Negeri 10 Yogyakarta dengan nilai koefisien korelasi sebesar 0.458 dengan $\mathrm{p}<0.01$; (2) Internal locus of control mempunyai hubungan positif dan signifikan terhadap perilaku prososial pelajar di SMA Negeri 10 Yogyakarta dengan nilai korelasi sebesar 0.590 dengan $\mathrm{p}<0.01$; (3) Kecerdasan emosi dan internal locus of control mempunyai hubungan yang signifikan dengan perilaku prososial pelajar di SMA Negeri 10 Yogyakarta. Besarnya sumbangan efektif kecerdasan emosional dan internal locus of control secara bersama-sama terhadap perilaku prososial sebesar 35.1\%, sedangkan sisanya yaitu $64.9 \%$ dipengaruhi oleh variabel lain yang tidak dimasukkan dalam penelitian ini. Sehingga disimpulkan bahwa pelajar di SMA Negeri 10 Yogyakarta yang menjadi responden memiliki kecerdasan emosional dan internal locus of control yang cenderung tinggi.
\end{abstract}

Kata kunci: kecerdasan emosional, internal locus of control, perilaku prososial

\section{THE RELATIONSHIP BETWEEN EMOTIONAL INTELLIGENCE AND INTERNAL LOCUS OF CONTROL WITH PROSOCIAL BEHAVIOR ON STUDENTS IN SMA NEGERI 10 YOGYAKARTA}

\author{
Meidy Dewita Artianasari Noija ${ }^{1}$, Kamsih Astuti $^{2}$ \\ ${ }^{12}$ Universitas Mercu Buana Yogyakarta \\ ²tutik.umby@gmail.com
}

\begin{abstract}
This study aims to determine the relationship between emotional intelligence and internal locus of control with prosocial behavior in students at SMAN 10 Yogyakarta. The method used in this study is the method of scale. The data collection is done by using a scale. The sampling technique used is non-random sampling. The subjects of this study were 80 students of XI IPA 1, XI IPA 2 and XI IPS 2 SMA Negeri 10 Yogyakarta. Data analysis was performed using product moment correlation analysis and multiple regression analysis. The results showed that: (1) emotional intelligence has a positive and significant relationship with prosocial behavior of SMAN 10 students in Yogyakarta with the correlation coefficient of 0458 with $p<0: 01$; (2) Internal locus of control has a positive and significant relationship to prosocial behavior of students in SMAN 10 Yogyakarta with a correlation value of 0,590 with $p<0: 01$; (3) Emotional intelligence and internal locus of control has a significant association with prosocial behavior of students at SMAN 10 Yogyakarta. The magnitude of the effective contribution of emotional intelligence and internal locus of control together toward prosocial behavior by $35.1 \%$, while the remaining $64.9 \%$ is influenced by other variables not included in this study. Thus, it can be concluded that the SMAN 10 Yogyakarta students who became respondents tended to have high emotional intelligence and internal locus of control.
\end{abstract}


Keywords: emotional intelligence, internal locus of control, prosocial behavior

\section{PENDAHULUAN}

Perkembangan dan pertumbuhan psikologis remaja dipengaruhi oleh lingkungan kehidupan. Lingkungan sosial remaja yang menerapkan pola pengasuhan kasih sayang, harmonis, tentram dan aman akan mendorong remaja tumbuh menjadi individu yang memiliki perilaku sesuai tatanan nilai dan norma yang diharapkan di masyarakat. Lingkungan pengasuhan yang demokratis dapat menumbuhan remaja memiliki perilaku prososial (Janssen dan Dekovic, 1997; Mahmud, 2003) sebaliknya remaja yang tumbuh dalam lingkungan sosial yang mengarah pada perilaku negatif, akan mendorong tumbuh menjadi individu yang berperilaku negatif.

Lingkungan sekolah merupakan salah satu lingkungan yang berpengaruh dalam berperilakunya pelajar. Pendidikan di sekolah inilah yang dapat membentuk perilaku pelajar. Tujuan dari prososial dalam bidang pendidikan adalah erat hubungannya dalam menjalin dan memelihara hubungan baik dengan orang lain, sehingga terlibat dalam bentuk menolong guru maupun teman-teman di lingkungan sekolah dan menerapkan perilaku tersebut (Akbar dan Listiara, 2012).

Pada dasarnya manusia adalah makhluk sosial yang selalu membutuhkan orang lain dalam menjalani kehidupannya sehari-hari. Manusia tidak dapat melepaskan diri dari lingkungannya, dan sebagai makhluk sosial setiap individu akan berinteraksi dengan individu lain guna memenuhi berbagai keperluan hidupnya. Manusia sebagai makhluk hidup dan makhluk sosial diharapkan mampu menyesuaikan diri dengan lingkungannya dengan jalan di samping memenuhi kebutuhan hidupnya sebagai makhluk individu juga melakukan berbagai kegiatan sosial dalam berinteraksi dengan orang lain. Salah satu bentuk perilaku sosial adalah adalah perilaku prososial. Perilaku prososial adalah perilaku menolong yang dilakukan oleh seseorang dengan ikhlas tanpa mengharapkan imbalan dari orang yang ditolong (Purnamasari, Ekowarni, \& Fadhila, 2004).

Perilaku prososial pelajar merupakan hal yang sangat penting, karena perilaku prososial tersebut adalah wujud partisipasi pelajar sebagai pribadi terpelajar, anggota masyarakat, dan warga negara. Perilaku prososial adalah segala bentuk perilaku yang memberikan keuntungan bagi individu atau kelompok, baik dalam bentuk materi, fisik ataupun psikologis serta bersifat sukarela (Dian, 2011). Berdasarkan pendapat tersebut maka dapat dikatakan bahwa perilaku prososial memiliki karakteristik seperti tindakan yang tidak menuntut keuntungan dan tindakan yang dilakukan secara suka rela.

Harapan perilaku prososial seseorang, khususnya pelajar adalah terjadinya perilaku saling tolong menolong tanpa mengharap imbalan dari pihak yang ditolong. Tidak hanya terbatas pada harapan bisa terjadi tindakan saling tolong menolong antar sesama, melainkan juga tindakan lain seperti berbagi, bekerja sama, menyumbang, dan senantiasa bertindak jujur setiap saat. Pelajar dalam tahap perkembangan sebagai remaja memiliki tugas 
perkembangan yang harus dipenuhi yang berhubungan dengan pentingnya perilaku prososial. Salah satu tugas perkembangannya adalah mencapai tingkah sosial yang bertanggungjawab, yang mana pelajar diharapkan untuk belajar berpartisipasi sebagai individu yang bertanggung jawab dalam kehidupan bermasayarakat serta menunjung tinggi nilai-nilai masyarakat dalam bertingkahlaku. Penelitian yang dilakukan oleh Gembeck, dkk. (dalam Akbar dan Listiara, 2012) mengungkapkan bahwa pelajar yang berperilaku prososial akan lebih diterima oleh lingkungan teman sebayanya dan begitu pula sebaliknya. Pelajar yang prososial senang terlibat dalam aktivitas-aktivitas sosial yang positif, sedangkan pelajar dengan kecenderungan prososial rendah lebih sering terlibat dalam aktivitas-aktivitas perilaku yang menyimpang. Berdasarkan pendapat tersebut, maka diketahui bahwa sangat penting bagi pelajar untuk berperilaku prososial. Perilaku prososial yang ditunjukkan oleh setiap orang dilatarbelakangi oleh beberapa faktor maupun karakteristik-karakteristik yang dimiliki. Salah satu karakteristik kepribadian penolong yang mendorong tingkah laku prososial adalah locus of control (Baron dan Bryne, 2005). Hasil penelitian yang dilakukan oleh Wilson dan Petruska (dalam Dayakisni dan Hudaniah, 2003) yang menunjukkan bahwa individu yang memiliki tingkat kecenderungan yang tinggi untuk melakukan tindakan prososial, biasanya memiliki karakteristik kepribadian yakni harga diri yang tinggi, rendahnya kebutuhan akan persetujuan orang lain, rendahnya penghindaran terhadap tanggung jawab, dan internal locus of control. Faktor lain yang terbukti berpengaruh terhadap perilaku prososial adalah kecerdasan emosional.

Kecerdasan emosional dikemukakan pertama kali oleh Daniel Goleman. Kecerdasan Emosional adalah kemampuan pribadi untuk membedakan dan menanggapi secara tepat suasana hati, kelakuan dan keinginan orang lain (Hardywinoto \& Setiabudhi, 2003). Kemampuan menggunakan keseimbangan antara emosi dan inteligensi tercakup dalam emotional intellegence (kecerdasan emosi). Kecerdasan emosi didefinisikan sebagai kemampuan untuk mengerti dan mengekspresikan emosi, mengolah emosi dalam pikiran, mengerti emosi dan mengatur emosi serta mengatur emosi dalam diri sendiri maupun terhadap orang lain (McShare dalam Hutapea dan Thoha, 2008).

Kecerdasan emosional adalah kemampuan seseorang mengatur kehidupan emosinya dengan inteligensi, menjaga keselarasan emosi dan pengungkapannya melalui keterampilan kesadaran diri, pengendalian diri, motivasi diri, empati, dan keterampilan sosial (Goleman dalam Bahtiar, 2009). Kecerdasan emosional didefinisikan sebagai kemampuan yang mengontrol emosi dan perasaan diri sendiri dan orang lain. Kemampuan ini kemudian digunakan sebagai pedoman untuk berpikir dan bertindak. Memahami kecerdasan emosional dan berusaha mengendalikannya adalah upaya untuk meningkatkan kualitas diri dan kehidupan (Saadan, Rajikon, Halim, \& Bokhari, 2011). Kecerdasan emosional adalah potensi bawaan untuk merasa, menggunakan, berkomunikasi, 
mengenali, ingat, menjelaskan, mengidentifikasi, belajar dari, mengelola, memahami dan menjelaskan emosi. Kecerdasan emosional yang terlibat dalam kapasitas untuk merasakan emosi, mengasimilasi perasaan emosi terkait, memahami informasi dari emosi, dan mengatur emosi. Kemampuan ini merupakan kemampuan untuk mengidentifikasi, menilai, dan mengendalikan emosi diri sendiri, orang lain, dan kelompok (Parveen, Malik, \& Aziz, 2012).

Kecerdasan emosi adalah kemampuan seseorang mengelola emosi dalam kaitannya dengan orang lain atau rangsangan dari luar. Kecerdasan emosi mencakup pengendalian diri terutama berkaitan dengan relasi, berempati kepada orang lain, mengelola rasa gembira dan sedih, semangat dan ketekunan, serta kemampuan untuk memotivasi diri (Sumardi, 2007).

Kecerdasan emosional diartikan sebagai kemampuan seseorang menggunakan emosi secara efektif dalam mengelola diri sendiri dan mempengaruhi hubungan dengan orang lain. Kecerdasan emosional penting dimiliki oleh setiap individu dalam menyikapi berbagai situasi yang terjadi, serta kepedulian terhadap kejadian-kejadian yang terjadi di sekeliling, seperti pemberian pertolongan kepada setiap orang yang mengalami kesulitan. Hal tersebut didukung oleh penelitian yang dilakukan oleh Marquez, Martín, \& Brackett (2006) menunjukkan bahwa pelajar dengan kecerdasan emosional yang tinggi, lebih menunjukkan sikap prososial dan memiliki performansi yang lebih baik di sekolah.
Selain faktor kecerdasan emosional, ada Faktor lain yang dapat mempengaruhi perilaku prososial pada pelajar adalah yang terkait dengan Internal Locus of Control.

Konsep tentang locus of control pertama kali dikemukakan oleh Rotter, seorang ahli teori pembelajaran sosial. Locus of control adalah cara pandang seseorang terhadap suatu peristiwa yang terjadi padanya (Ida dan Dwinta, 2010). Locus of control yang disebut dengan istilah kendali atau kontrol berhubungan dengan pendekatan kognitif yang digunakan. Rotter (dalam Widawati, 2011) memandang locus of control sebagai variabel sentral dalam struktur kepribadian yang implisit dalam proses belajar, dan akan memengaruhi tingkah laku aktual, mewarnai sikap dan kehidupan perasaan, pusat hirarki dalam pola pikir, serta mendasari tingkah laku penyesuaian diri maupun antisipasi.

Larsen dan Buss (dalam Ida dan Dwinta, 2010) mendefinisikan locus of control sebagai suatu konsep yang menunjuk pada keyakinan individu mengenai peristiwa-peristiwa yang terjadi dalam hidupnya. Locus of control menggambarkan seberapa jauh seseorang memandang hubungan antara perbuatan yang dilakukannya (action) dengan akibat/hasilnya (outcome). Locus of control diartikan sebagai persepsi seseorang tentang sebab-sebab keberhasilan atau kegagalan dalam pelaksanaan pekerjaannya. Locus of control adalah bagaimana seorang individu mengartikan sebab dari suatu peristiwa.

Internal locus of control adalah cara dimana seseorang yakin kontrol terhadap peristiwa berasal dari kemampuannya. Selain 
itu, individu yang memiliki internal locus of control memahami bahwa hasil yang diperoleh tergantung pada seberapa banyak usaha yang dilakukan. Internal locus of control merupakan keyakinan seseorang bahwa kejadian dalam hidupnya ditentukan oleh kemampuannya sendiri. Individu yang memiliki internal locus of control memahami bahwa hasil yang diperoleh tergantung pada seberapa banyak usaha yang dilakukan (Rotter dalam Jaya dan Rahmat, 2005).

Individu yang memiliki internal locus of control memiliki keyakinan bahwa dirinya dapat mengatur dan mengarahkan hidupnya serta bertanggung jawab terhadap pencapaian penguat apapun yang diterimanya sehingga ketika dihadapkan pada suatu masalah, maka akan melakukan usaha untuk mengenali masalah, mencari tahu tentang langkah-langkah penyelesaian, mencari alternatif yang terbaik serta berusaha mengatasi masalah berkaitan dengan masalah tersebut (Saputra dan Satiningsih, 2013).

Orang yang memiliki pembawaan Internal Locus of Control adalah orang yang percaya bahwa hasil dari suatu aktivitas sangat tergantung pada usaha dan kerja keras dari orang itu sendiri (Hidayat dan Handayani, 2010). Menurut Crider (dalam Srimulyani, 2013). Seseorang dikatakan memiliki Internal Locus of Control tinggi ketika memenuhi aspekaspek yang terdiri dari suka bekerja keras, memiliki inisiatif yang tinggi, selalu berusaha untuk menemukan pemecahan masalah, selalu mencoba untuk berpikir seefektif mungkin, dan selalu mempunyai persepsi bahwa usaha harus dilakukan jika ingin berhasil. Locus of Control internal merupakan salah satu di antara faktor kepribadian seseorang yang memiliki pengaruh yang besar terhadap perilaku prososial. Locus of Control berperan untuk memberikan pengaruh dan menentukan individu untuk mengambil keputusan, di mana proses dalam melkukan perilaku prososial selalu diperlukan sikap tanggung jawab pribadi dan keberanian untuk mengambil keputusan. Dengan demikian, maka seseorang yang memiliki Locus of Control internal, maka memiliki kemungkinan lebih besar untuk berani mengambil tanggung jawab pribadi dan berani mengambil tindakan dibandingkan dengan seseorang yang memiliki internal Locus of Control rendah.

Dari beberapa pengertian di atas, dapat ditarik kesimpulan bahwa internal locus of control menunjuk pada keyakinan yang ada dalam diri individu bahwa dirinya memiliki kontrol akan hal-hal yang terjadi dalam hidupnya. Dengan demikian, orang yang memiliki internal locus of control memahami bahwa hasil yang diperoleh tergantung pada seberapa banyak usaha yang dilakukan.

\section{METODE}

Perilaku prososial dalam penelitian ini diartikan sebagai suatu tindakan yang dilakukan untuk menolong orang lain tanpa mempedulikan motif dari penolong. Sehingga tindakan prososial bersifat sukarela atau lebih ditunjukkan untuk menguntungkan orang lain daripada untuk mendapat imbalan. Perilaku prososial diukur dengan skala perilaku prososial disusun mengacu pada pendapat Mussen, dkk, (dalam Asih dan Pratiwi, 2010) yang meliputi : a). Berbagi (sharing), yaitu kesediaan untuk 
berbagi perasaan dengan orang lain dalam suasana suka dan duka. b). Kerjasama (cooperative), yaitu kesediaan untuk bekerjasama dengan orang lain demi tercapainya suatu tujuan. c). Menyumbang (donating) yaitu kesediaan untuk memberikan sebagian barang miliknya tanpa paksaan kepada orang yang mengalami kesusahan. d). Menolong (helping), yaitu kesediaan untuk menolong orang lain yang sedang berada dalam kesulitan.

Jumlah pernyataan aitem pada skala perilaku prososial adalah 36 aitem yang terdiri dari 18 aitem favourable dan 18 aitem unfavourable. Hasil uji validitas pada skala Perilaku Prososial yang digunakan menggunakan skor kriteria 0,3 terdapat 7 aitem yang gugur, sehingga aitem valid sebanyak 29 aitem. Nilai koefisien validitas aitem yang valid pada skala Perilaku Prososial berkisar 0,337 0,651 . Hasil uji reliabilitas yang telah dilakukan dapat diketahui nilai cronbach alpha pada variabel skala Perilaku Prososial adalah sebesar 0,905 mempunyai nilai cronbach alpha lebih besar dari 0,6, artinya skala Variabel Perilaku Prososial dinyatakan reliabel.

Kecerdasan emosional dalam penelitian ini diartikan sebagai kemampuan seseorang menggunakan emosi secara efektif dalam mengelola diri sendiri dan mempengaruhi hubungan dengan orang lain. Menurut Goleman (1999) kecerdasan emosional dapat diukur dengan menggunakan skala kecerdasan emosional, yang di susun dengan mengacu pada a). Mengenali emosi diri adalah kesadaran diri untuk mengenali perasaan sewaktu perasaan itu terjadi. b). Mengelola emosi adalah kemampuan pelajar dalam mengungkap dan menangani perasan-perasaannya dengan pas pada obyek yang tepat. c). Memotivasi dan memahami diri sendiri adalah kemampuan pelajar untuk memahami perasaan sendiri akan memunculkan sikap bijaksana dalam mengambil keputusan, serta dapat mengungkapkan emosinya secara selaras. d). Mengenal emosi orang lain adalah kemampuan pelajar untuk menangkap sinyalsinyal sosial yang tersembunyi, yang mengisyaratkan apa yang dibutuhkan atau dikehendaki oleh orang lain. e). Membina hubungan adalah kemampuan pelajar untuk membentuk hubungan, membina kedekatan hubungan, meyakinkan, mempengaruhi dan membuat orang lain nyaman, serta dapat menjadi pendengar yang baik.

Jumlah pernyataan aitem pada skala kecerdasan emosional adalah 40 aitem yang terdiri dari 20 aitem favourable dan 20 aitem unfavourable. Hasil uji validitas pada skala Kecerdasan Emosional yang digunakan menggunakan skor kriteria 0,3 terdapat 7 aitem yang gugur, sehingga aitem valid sebanyak 33 aitem. Nilai koefisien validitas aitem yang valid pada skala Kecerdasan Emosional berkisar 0,311 - 0,701. Hasil uji reliabilitas yang telah dilakukan dapat diketahui nilai cronbach alpha pada variabel skala Perilaku Prososial adalah sebesar 0,909, karena nilai cronbach alpha lebih besar dari 0,6 artinya skala Variabel Kecerdasan Emosional dikatakan reliabel.

Internal locus of control dalam penelitian ini diartikan sebagai keyakinan yang ada dalam diri individu bahwa dirinya memiliki kontrol akan hal-hal yang terjadi dalam hidupnya. Internal locus of control diukur dengan skala 
internal locus of control disusun dengan mengacu pada pendapat Crider dalam Srimulyani (2013) yang meliputi : a). Suka bekerja keras adalah pelajar selalu memiliki kepercayaan bahwa antara usaha dan keberhasilan selalu berkorelasi. b). Memiliki inisiatif yang tinggi adalah pelajar selalu memiliki inisiatif yang tinggi untuk dapat menghadapi permasalahannya. c). Selalu berusaha untuk menemukan pemecahan masalah adalah pelajar selalu merasa bahwa kontrol berasal dari dalam dirinya, sehinga mau berusaha. d). Selalu mencoba untuk berpikir seefektif mungkin adalah pelajar selalu memikirkan apa yang akan dilakukan di waktu mendatang. e). Selalu mempunyai persepsi bahwa usaha harus dilakukan jika ingin berhasil adalah pelajar mempunyai persepsi bahwa keberhasilan berasal dari usaha yang dilakukan oleh diri sendiri.

Jumlah pernyataan aitem pada skala internal locus of control adalah 40 aitem yang terdiri dari 20 aitem favourable dan 20 aitem unfavourable. Hasil uji validitas pada skala Internal Locus of Control yang digunakan menggunakan skor kriteria 0,3 terdapat 8 aitem yang gugur, sehingga aitem valid sebanyak 32 aitem. Nilai koefisien validitas aitem yang valid pada skala Internal Locus of Control berkisar 0,369 - 0,729. Hasil uji reliabilitas yang telah dilakukan dapat diketahui nilai cronbach alpha pada variabel skala Internal Locus of Control adalah sebesar 0,916, karena mempunyai nilai cronbach alpha lebih besar dari 0,6 artinya skala Variabel Internal Locus of Control dinyatakan reliabel.
Dalam penelitian ini penentuan sampel menggunakan teknik non random sampling, yaitu bahwa pemilihan sampel dengan cara ini tidak menghiraukan prinsip-prinsip probability. Pengambilan sampel dilakukan dengan teknik purposive sampling yaitu pengambilan sampel dilakukan hanya atas dasar pertimbangan peneliti saja yang menganggap unsur-unsur yang dikehendaki telah ada dalam anggota sampel yang diambil (Nazution, 2003).

Sebelum melakukan pengambilan data penelitian maka peneliti melakukan uji validitas dan reliabilitas instrumen yakni dengan mengambil sampel uji coba sebanyak 60 responden. Peneliti mengambil 3 kelas yakni kelas XI IPA 4, kelas XI IPA 3, dan kelas XI IPS. Setelah instrumen penelitian dinyatakan valid dan reliabel, selanjutnya peneliti melakukan pengambilan data penelitian yang digunakan sebagai data primer dalam penelitian ini. Responden dalam penelitian ditentukan sebanyak 80 pelajar yang berasal dari tiga kelas, yaitu Kelas XI IPA 1, Kelas XI IPA 2, dan Kelas XI IPS 2.

Metode pengumpulan data yang digunakan dalam penelitian ini adalah metode skala. Dalam penelitian ini alat ukur yang digunakan adalah skala yang terdiri dari skala perilaku prososial, skala kecerdasan emosional, dan skala internal locus of control. Aitem-aitem dalam skala ini dibuat bervariasi antara pernyataan yang bersifat favourable dan unfavourable, hal ini dilakukan untuk menghindari stereotipe jawaban. Aitem-aitem yang digunakan dalam penelitian ini dilakukan uji validitas dan reliabilitas. Setiap aitem pada variabel perilaku prososial (Y) mempunyai 4 
kemungkinan jawaban yaitu: Selalu (SL), Sering (SR), Kadang-kadang (KD), dan Tidak Pernah (TP). Sedangkan pada aitem-aitem dari variabel Kecerdasan Emosi (X1) dan Internal Locus of Control (X2) mempunyai kemungkinan jawaban, yaitu sangat sesuai (SS), sesuai (S), tidak sesuai (TS), dan sangat tidak sesuai (STS).

Data penelitian perilaku prososial, kecerdasan emosional, dan internal locus of control diperoleh dengan cara membagikan skala perilaku prososial, kecerdasan emosional, dan internal locus of control kepada pelajar SMA N 10 Yogyakarta kelas XI IPA 4, kelas XI IPA 3, dan kelas XI IPS 1 sebagai subjek penelitian untuk diisi dengan cara memberi tanda silang (X) pada setiap kolom pernyataan sesuai dengan kondisi yang dialami oleh pelajar. Pelajar yang menjadi subjek peneliti mengisi skala di kelas masing-masing. Setelah pelajar mengisi skala perilaku prososial, kecerdasan emosional, dan internal locus of control maka peneliti menarik kembali skala tersebut dan menghitung perolehan skor masing-masing subjek penelitian.

\section{HASIL DAN PEMBAHASAN}

\section{Hasil Penelitian.}

Hipotesis 1 dan hipotesis 2 diuji dengan menggunakan uji korelasi product moment. Analisis ini bertujuan untuk mengetahui hubungan antara variabel independen dengan variabel dependen. Dari tabel korelasi diketahui bahwa kecerdasan emosional memiliki korelasi positif dengan perilaku prososial yang dapat dilihat hasil $r=0.458(\mathrm{p}<0.05)$. Sedangkan dari tabel korelasi juga terlihat internal locus of control juga memiliki korelasi positif dengan perilaku prososial, dapat dilihat dari nilai $\mathrm{r}=$ $0.590(\mathrm{p}<0.05)$. variabel kecerdasan emosional mempunyai hubungan positif dan signifikan dengan perilaku prososial dengan nilai koefisien korelasi sebesar 0.458 dan nilai sig.sebesar 0.000. Variabel internal locus of control mempunyai hubungan positif dan signifikan terhadap perilaku prososial dengan nilai korelasi sebesar 0.590 dan nilai sig.sebesar 0.000. Hal ini menunjukkan bahwa hipotesis 1 dan hipotesis 2 diterima.

Hipotesis 3 diuji dengan menggunakan uji regresi liner berganda. Analisis regresi ganda digunakan untuk meramalkan bagaimana keadaan (naik-turunnya) variabel dependen, bila dua atau lebih variabel independen sebagai prediktor dimanipulasi (dinaik-turunkan nilainya). Jadi analisis regresi ganda akan dilakukan jika jumlah variabel independennya minimal dua (Sugiyono, 2010). Model regresi dinyatakan signifikan jika koefiesien signifikannya $\mathrm{p}<0.05$, dan jika taraf signifikansi $\mathrm{p}>0.05$, maka model regresi dinyatakan tidak signifikan. Dalam penelitian ini analisis regresi juga digunakan untuk menjawab apakah ada peranan kecerdasan emosi dan internal locus of control terhadap perilaku prososial.

Pengujian yang dilakukan juga diperoleh nilai F yaitu sebesar 20.807, sehingga dapat disimpulkan bahwa secara bersama-sama kecerdasan emosi dan internal locus of control mempunyai hubungan yang signifikan dengan perilaku prososial. Hasil analisis menunjukkan besar koefisien korelasi (R) adalah sebesar 0.592. Dari pengujian yang dilakukan juga 
diketahui bahwa besarnya nilai Koefisien Determinasi $\left(\mathrm{R}^{2}\right)$ variabel X1 dan X2 terhadap $\mathrm{Y}$ sebesar 0.351 mempunyai arti bahwa besarnya sumbangan efektif kecerdasan emosional dan internal locus of control secara bersama-sama terhadap perilaku prososial sebesar $35.1 \%$, sedangkan sisanya yaitu $64.9 \%$ dipengaruhi oleh variabel lain, misalnya gender, pola asuh orang tua, tayangan televisi, dan lain sebagainya.

\section{Pembahasan}

\section{a. Perilaku Prososial.}

Berdasarkan hasil uji korelasi Product Moment diketahui bahwa terdapat hubungan positif dan signifikan antara kecerdasan emosional dengan perilaku prososial dan ada hubungan positif dan signifikan antara Internal Locus of Control dengan perilaku prososial. Dari uji regresi berganda dapat diketahui bahwa secara bersama-sama ada hubungan kecerdasan emosional dan Internal Locus of Control terhadap perilaku prososial. Berdasarkan pada penelitian yang telah penulis lakukan, dapat diketahui bahwa tingkat perilaku prososial pada pelajar SMA Negri 10 Jogjakarta kelas XI cenderung tinggi. Hal ini dapat dilihat dari hasil kategorisasi subjek yang memiliki perilaku prososial klasifikasi rendah sebanyak $0 \%$, sedang sebanyak $10 \%$ dan tinggi $90 \%$. Dari hasil ini dapat disimpulkan bahwa hasil perilaku prososial subjek cenderung tinggi.

\section{b. Kecerdasan Emosional.}

Hasil analisa yang dilakukan dalam penelitian ini menunjukan bahwa kecerdasan emosional memiliki korelasi positif dengan perilaku prososial. Hal ini dapat dilihat dari hasil $\mathrm{r}=0.458(\mathrm{p}<0.05)$, yang berarti bahwa apabila kecerdasan emosional pelajar tinggi maka perilaku prososial juga akan semakin tinggi. Sebaliknya, jika kecerdasan emosional pelajar rendah maka perilaku prososial pelajar tersebut juga akan rendah. Adapun alasan yang bisa dijadikan sebagai dasar terkait dengan kesimpulan ini adalah karena kecerdasan emosi dapat menempatkan emosi seseorang pada porsi yang tepat, memilah kepuasan dan mengatur suasana hati. Koordinasi suasana hati adalah inti dari hubungan sosial yang baik. Apabila seseorang pandai menyesuaikan diri dengan suasana hati individu yang lain atau dapat berempati, orang tersebut akan memiliki tingkat emosionalitas yang baik dan akan lebih mudah menyesuaikan diri dalam pergaulan sosial serta lingkungannya. Hasil penelitian ini sejalan dengan apa yang diungkapkan oleh Glock \& Stark (dalam Haque dan Rahmasari, 2013) yang menjelaskan bahwa dengan latar kepribadian yang baik, individu akan mempunyai orientasi sosial yang tinggi sehingga cenderung lebih mudah memberi pertolongan. Latar belakang kepribadian yang mempengaruhi perilaku diantaranya adalah kecerdasan emosional. Hasil penelitian lain adalah penelitian Nashori (dalam Haque dan Rahmasari, 2013) yang menunjukkan bahwa ada hubungan antara besarnya empati dengan kecenderungan menolong. Empati merupakan salah satu dari lima kemampuan utama yang mendasari kecerdasan emosional. Hubungan antara empati dengan perilaku menolong secara konsisten ditemukan pada semua kelompok umur, sehingga hubungan empati dengan perilaku menolong tidak hanya pada remaja, melainkan 
juga para orang dewasa. Empati merupakan kemampuan meletakkan diri sendiri dalam posisi orang lain dan menghayati pengalaman tersebut. Dengan bahasa yang lain empati adalah kemampuan seseorang dalam ikut merasakan atau menghayati perasaan dan pengalaman orang lain dengan tidak hanyut dalam suasana orang lain melainkan memahami apa yang dirasakan orang lain. Disamping itu empati bisa berarti kemampuan untuk mendeteksi perbedaan-perbedaan dalam diri orang lain dan memiliki kapasitas untuk menerima sudut pandang orang lain dengan tujuan untuk memahami keadaan emosional orang tersebut. Haque dan Rahmasari (2013) menyatakan bahwa kecerdasan emosional memiliki hubungan signifikan dengan perilaku prososial dengan arah hubungan yang positif.

Dari hasil penelitian ini diketahui, bahwa kecerdasan emosi pada pelajar SMA Negri 10 Jogjakarta kelas XI adalah cukup tinggi. Hal ini dapat diketahui dari hasil klasifikasi evaluatif skala kecerdasan emosional. Hasil klasifikasi menunjukan bahwa sebagian besar pelajar memiliki kecerdasan emosional yang sedang $(32.5 \%)$, sisanya sebanyak $(67.5 \%)$ pelajar memiliki kecerdasan emosional cenderung tinggi. Kecerdasan emosional memberikan sumbangan sebesar 45,8\% terhadap perilaku prososial.

Berdasarkan uraian diatas dapat dinyatakan bahwa kecerdaan emosional penting dimiliki oleh setiap pelajar dalam menyikapi berbagai situasi yang terjadi, serta kepedulian terhadap kejadian-kejadian yang terjadi di sekeliling, seperti pemberian pertolongan kepada setiap orang yang membutuhkan dan hal tersebut merupakan salah satu komponen penting dari perilaku prososial.

\section{c. Internal Locus of Control.}

Internal Locus of Control juga berhubungan dengan prososial. Pada hasil analisis yang dilakukan diketahui bahwa ada hubungan positif antara Internal Locus of Control dengan perilaku prososial. Hal ini dapat dilihat dari hasil uji korelasi antara Internal Locus of Control dengan perilaku prososial sebesar $\mathrm{r}=0.590(\mathrm{p}<0.05)$. hasil ini menunjukan bahwa jika Internal Locus of Control yang dimiliki oleh pelajar kelas X1 tinggi maka perilku prososial akan tinggi. Sebaliknya jika Internal Locus of Control rendah maka perilaku prososial pun menjadi rendah.

Dari hasil penelitian yang dilakukan penulis, diketahui juga bahwa tingkat internal locus of control pada pelajar SMA Negri 10 Jogjakarta kelas XI cenderung tinggi. Hal ini dapat diketahui dari hasil klasifikasi skala internal locus of control. Hasil evaluasi menunjukan bahwa sebagian besar pelajar $(16,3 \%)$ memiliki internal locus of control sedang, sisanya sebanyak $83.8 \%$ memiliki internal locus of control tinggi. Internal locus of control memberikan sumbangan sebesar 59\% terhadap perilaku sosial.

Hasil penelitian ini sejalan dengan penelitian yang dilakukan oleh Putra (2004) yang menyatakan bahwa terdapat hubungan yang signifikan antara Internal Locus of Control dengan intensi prososial. Orang yang memiliki pembawaan Internal Locus of Control adalah orang yang percaya bahwa hasil dari suatu 
aktivitas sangat tergantung pada usaha dan kerja keras dari orang itu sendiri (Hidayat dan Handayani, 2010). Pelajar yang cenderung mempunyai Internal Locus of Control akan mempunyai sikap positif terhadap apa yang terjadi pada dirinya dan lingkungan sekitarnya. Sikap positif tersebut yang akan mendorong siswa untuk melakukan tindakan-tindakan prososial (Kamasanthi, 2008).

Ervina (2010) mengemukakan bahwa Internal Locus of Control merupakan salah satu faktor kepribadian yang berpengaruh terhadap perilaku prososial. Internal Locus of Control berperan dalam mempengaruhi dan menentukan individu untuk pengambilan keputusan, di mana proses dalam melakukan perilaku prososial diperlukan tanggung jawab pribadi dan keberanian dalam mengambil keputusan. Orang yang mempunyai Internal Locus of Control akan mengambil tanggung jawab pribadi dan berani dalam mengambil tindakan dibandingkan dengan orang dengan kecenderungan Internal Locus of Control yang rendah. Orang yang Internal Locus of Control-nya rendah cenderung kurang percaya diri dan kurang berani dalam mengambil tindakan, sehingga orang yang memiliki Internal Locus of Control yang tinggi akan lebih prososial.

Dari hasil penelitian yang dilakukan penulis, diketahui juga bahwa tingkat internal locus of control pada pelajar SMA Negri 10 Jogjakarta kelas XI cenderung tinggi. Hal ini dapat diketahui dari hasil klasifikasi skala internal locus of control. Hasil evaluasi menunjukan bahwa sebagian besar pelajar $(16,3 \%)$ memiliki internal locus of control sedang, sisanya sebanyak $83.8 \%$ memiliki internal locus of control tinggi. Selanjutnya internal locus of control mempunyai hubungan yang positif dan signifikan dengan perilaku prososial. Hal ini terlihat dari uji korelasi dan uji regresi pada penelitian ini yang mendapatkan hasil yang signifikan. Artinya, semakin tinggi internal locus of control maka semakin tinggi pula perilaku prososial pelajar. Internal locus of control memberikan sumbangan sebesar $59 \%$ terhadap perilaku sosial.

Hasil penelitian ini sejalan dengan penelitian yang dilakukan oleh Putra (2004) yang menyatakan bahwa terdapat hubungan yang signifikan antara Internal Locus of Control dengan intensi prososial. Orang yang memiliki pembawaan Internal Locus of Control adalah orang yang percaya bahwa hasil dari suatu aktivitas sangat tergantung pada usaha dan kerja keras dari orang itu sendiri (Hidayat dan Handayani, 2010). Pelajar yang cenderung mempunyai Internal Locus of Control akan mempunyai sikap positif terhadap apa yang terjadi pada dirinya dan lingkungan sekitarnya. Sikap positif tersebut yang akan mendorong siswa untuk melakukan tindakan-tindakan prososial (Kamasanthi, 2008).

Berdasarkan analisis yang telah dilakukan dengan menggunakan teknik analisis regresi, maka ditemukan adanya korelasi antara kecerdasan emosional dan internal locus of control dengan perilaku prososial. Berdasarkan pengujian yang dilakukan juga diperoleh nilai $\mathrm{F}$ yaitu sebesar 20.807, sehingga dapat disimpulkan bahwa secara bersama-sama kecerdasan emosi dan internal locus of control mempunyai hubungan yang signifikan dengan 
perilaku prososial. Hasil analisis menunjukkan besar koefisien korelasi (R) adalah sebesar 0.592. Koefisien determinasi $\left(\mathrm{R}^{2}\right)$ sebesar 0.351 berarti bahwa sebesar $35.1 \%$ perilaku prososial pelajar dipengaruhi oleh kecerdasan emosional dan Internal Locus of Control, sedangkan sisanya sebesar $64.9 \%$ dipengaruhi oleh variabel lain, misalnya gender, pola asuh orang tua, tayangan televisi, dan lain sebagainya.

Hasil penelitian ini sejalan dengan penelitian yang dilakukan oleh Astuti (2012) menyebutkan bahwa ada faktor yang dapat mempengaruhi kecenderungan seseorang untuk memberikan pertolongan kepada orang lain, yaitu: dilihat dari latar belakang kepribadian penolong, yang memiliki ciri-ciri: empati yang tinggi, memiliki kepercayaan bahwa dunia itu adil, mempunyai tanggung jawab sosial tinggi, memiliki Internal Locus of Control, serta egoisme yang rendah. Sears, Freedman, \& Peplau (2004) mengemukakan bahwa faktorfaktor yang mempengaruhi perilaku prososial dilihat dari karakteristik penolong diantaranya adalah kecerdasan emosional dan Internal Locus of Control.

\section{KESIMPULAN}

Berdasarkan hasil penelitian dapat disimpulkan bahwa:

1. Kecerdasan emosional mempunyai hubungan positif dan signifikan dengan perilaku prososial pelajar di SMA Negeri 10 Yogyakarta. Semakin tinggi kecerdasan emosional pelajar maka perilaku prososialnya juga akan cenderung semakin tinggi, sebaliknya semakin rendah kecerdasan emosional pelajar maka semakin rendah pula perilaku prososialnya. Kecerdasan emosional merupakan salah satu faktor yang berpengaruh terhadap perilaku prososial pelajar. Pelajar di SMA Negeri 10 Yogyakarta yang menjadi responden memiliki kecerdasan emosional pada kategori tinggi.

2. Internal locus of control mempunyai hubungan positif dan signifikan terhadap perilaku prososial pelajar di SMA Negeri 10 Yogyakarta. Semakin tinggi internal locus of control pelajar, maka akan cenderung semakin tinggi pula perilaku prososialnya. Sebaliknya, semakin rendah internal locus of control yang dimiliki pelajar maka akan cenderung semakin rendah pula perilaku prososialnya. Pelajar di SMA Negeri 10 Yogyakarta yang menjadi responden memiliki internal locus of control sebagian besar berada di kategori tinggi.

3. Kecerdasan emosi dan internal locus of control mempunyai hubungan yang signifikan dengan perilaku prososial pelajar di SMA Negeri 10 Yogyakarta. Besarnya sumbangan efektif kecerdasan emosional dan internal locus of control secara bersama-sama terhadap perilaku prososial sebesar $35.1 \%$, sedangkan sisanya yaitu $64.9 \%$ dipengaruhi oleh variabel lain, misalnya gender, pola asuh orang tua, tayangan televisi, dan lain sebagainya. 


\section{DAFTAR PUSTAKA}

Akbar, Z.Y., \& Listiara, A. (2012). The difference between the prosocial tendensi regular classes and special classes at SMA N 1 and SMA N 3 Semarang. Jurnal Psikologi, 1(1), 120-138

Asih, G.Y., \& Pratiwi, M.M.S. (2010). Perilaku prososial ditinjau dari empati dan kemantangan emosi. Jurnal Psikologi Universitas Muria Kudus, 1(1), 33-42

Baron, R.A., \& Byrne, D. (2005). Psikologi sosial, edisi kesepuluh (Diterjemahkan oleh: Ratna Juwita). Jakarta: Erlangga

Dayakisni, T., \& Hudaniah. (2009). Psikologi sosial (edisi revisi). Malang: UMM Press

Dian, E. (2011). Perbedaan perilaku prososial pada remaja ditinjau dari persepsi terhadap perilaku orang tua sebagai figur kelekatan (Attachment) http://dglib.uns.ac.id/pengguna.php?mn=s howview\&id=17859, diakses tanggal tanggal 26 Juni 2013

Ervina. (2010). Hubungan locus of control Internal dengan perilaku prososial pada remaja panti asuhan. Tesis. Malang: Universitas Muhammadiyah Malang.

Goleman, D. (1999). Emotional intellegence, kecerdasan emosional, mengapa EQ lebih penting daripada IQ (Diterjemahkan oleh: T. Hermaya). Jakarta: PT Gramedia Pustaka Utama.

Goleman,D. (2001). Kecerdasan emosi untuk mencapai puncak prestasi (Diterjemahkan oleh: Alex Tri Kantjono Widodo). Jakarta: PT Gramedia Pustaka Utama.

Hidayat, W., \& Handayani, S. (2010). Peran Faktor-Faktor Individual dan Pertimbangan Etis terhadap Perilaku Auditor dalam Situasi Konflik Audit pada Lingkungan Inspektorat Sulawesi Tenggara. Mitra Ekonomi dan Manajemen Bisnis, 1(1), 83-112.

Jaya, E.D., \& Rahmat, I. (2005). Burnout ditinjau dari locus of control internal dan eksternal. Majalah Kedokteran Nusantara, 38(3), 213-218.
Jansenns, J. MAM., \& Dekovic,M. (1997). Child rearing, prososial reasoning and prososial behavior. International Journal of Behavioral Develepment, 20(3), 509527.

Kamasanthi, T. (2008). Hubungan locus of control dengan komitmen organisasi pada karyawati yang berumah tangga di PT. X Tangerang. Jurnal Psikologi, 6(2), 63-69.

Marquez, P.G., Martín, R.P., \& Brackett, M.A. (2006). Relating emotional intelligence to social competence and academic achivement in high school student. Psichothema 2006, 18, 118-123.

Parveen, A., Malik, M.H., \& Aziz, R. (2012). Emotional intelligence and academic Achievement of male and female adolescent students of District Budgam. Journal of Education and Practice, 3(15), 184-186.

Purnamasari, A., Ekowarni, E., \& Fadhila. A. (2004). Perbedaan intensi prososial siswa SMU Negeri dan MAN di Yogyakarta. Humanitas: Indonesian Psychologycal Journal, 1(1), 32-42.

Putra. (2004). Internal locus of control dan imitasi model dengan intensi prososial mahasiswa jurusan keperawatan poltekkes Malang, http://www.poltekkesmalang.ac.id/jurnalmei.htm\#internal,diakses tanggal $17 \mathrm{Juli}$ 2009.

Srimulyani, V.A. (2013). Analisis pengaruh kecerdasan adversitas, internal locus of control, kematangan karir terhadap intensi berwirausaha pada mahasiswa bekerja (studi empiris pada mahasiswa kelas karyawan Unika Widya Mandala Madiun). Widya Warta, 37(1), 96-11.

Sumardi. (2007). Password menuju sukses (rahasia membangun sukses individu, lembaga, dan perusahaan). Jakarta: Erlangga 